\title{
Rzeczpospolita wobec aneksji Krymu przez Rosję w 1783 roku
}

Ostatnie ćwierćwiecze XVIII w. przyniosło zasadnicze zmiany w układzie sił na Morzu Czarnym i na Bałkanach. Takie wydarzenia, jak traktat w Küczuk Kainardżi (1774 r.), czy aneksja Krymu (1783 r.) wzbudziły niepokój nie tylko w Stambule, ale również w innych stolicach europejskich. Na poczynania Katarzyny II i jej dalsze plany wobec Turcji patrzono nawet $\mathrm{w}$ Londynie $z$ rosnacym niepokojem ${ }^{1}$. Jednak sukcesy oręża rosyjskiego okazały się na tyle silnym argumentem, że wszelkie dyskusje na temat utrzymania status quo w tym regionie były bezskuteczne ${ }^{2}$. Ekspansja imperium Katarzyny II we wspomnianym kierunku niosła za soba intensywna kolonizacje południowych prowincji państwa rosyjskiego i zaanektowanych terytoriów, która kierował książę taurydzki (od 1784 r.) Grigorij Potiomkin ${ }^{3}$. W 1778 r. caryca wezwała wszystkich chrześcijan przebywających na Krymie do przesiedlenia się na tereny południowych guberni rosyjskich. Dzięki pomocy armii operacja ta została przeprowadzona sprawnie i około 30000 osób opuściło granice Chanatu Krymskiego. Jednocześnie nad Dnieprem zaczęto budowę dużych ośrodków miejskich (Jekaterynosław, Chersoń). Potiomkin był w swoim żywiole, patronował lub nawet osobiście opracowywał projekty kolonizacji rosyjskiego Południa.

1 V. C r o n i n, Katarzyna II. Imperatorowa Wszechrosji, Kraków 2000, s. 300.

2 A.W. F i s h e r, Russian Annexation of Crimea 1772-1783, Cambridge 1970, passim.

3 S.S. M o n t e fi o r e, Potiomkin. Ksiażę Ksiażat, Warszawa 2006, s. 287-346; S.G. Wod otika, E.G. Sinkievicz, Istoria Chersonszcziny, Chersoń 2003, s. 46-49. 
Traktat w Küczuk Kainardżi nie stanowił w sprawie Krymu zadowalającego rozwiązania zarówno dla Rosji, która nie kryła swych apetytów na aneksję ziem Chanatu, jak i zwłaszcza dla Turcji, chcącej przywrócić stan sprzed 1774 r. Rosyjsko-turecka konwencja w Ainali-Kawak z 1779 r. potwierdziła warunki traktatu w Küczuk Kainardżi, ponieważ żadne $z$ państw europejskich nie chciało wówczas interweniować $\mathrm{w}$ sprawie utrzymania równowagi $\mathrm{w}$ basenie Morza Czarnego. Turcja zobowiązała się uznać dożywotnią władzę prorosyjskiego chana Szahina Gireja, nie mieszać się w wewnętrzne sprawy Krymu, zrezygnowała też $z$ religijnego zwierzchnictwa nad Chanatem. Rosja $z$ kolei obiecała wycofać swoje wojska $z$ Krymu, oddała też Turcji skrawek terenu koło Oczakowa. W kolejnych latach trwały spory chana $z$ opozycja, mnożyły się rozruchy, które stały się doskonałym pretekstem do interwencji rosyjskiej. Latem 1782 r. armia carska pod dowództwem Potiomkina wkroczyła na Krym i rozproszyła powstańców. Pod osłona bagnetów rosyjskich Szahin Girej powrócił do Bachczysaraju i rozpoczął ostre represje wobec przeciwników politycznych, co jednak nie doprowadziło do stabilizacji. Katarzyna II i jej faworyt postanowili wobec tego zakończyć „tatarska anarchię”.

Jeszcze w 1782 r. Potiomkin sondował wśród arystokracji tatarskiej opinie na temat przyłączenia Krymu do Rosji ${ }^{4}$. W memoriale skierowanym do carycy uzasadniał konieczność włączenia tego obszaru pod jej panowanie ${ }^{5}$. W marcu 1783 r. przebywał w Petersburgu, gdzie omawiał z Katarzyną II szczegółowy plan aneksji Kry$\mathrm{mu}$. Jeszcze wtedy liczono się $z$ reakcja stolic europejskich, ale wątpliwości te rozwiał list od cesarza austriackiego Józefa II, w którym nie znaleziono podstaw do obaw o podjęcie zdecydowanych kroków w obronie niepodległości Chanatu. W Petersburgu liczono się jedynie $z$ tym, że ekspansja spotka się $z$ kontrakcją Prus, co może doprowadzić do konfliktu militarnego lub zgody na ekwiwalenty dla króla Fryderyka II w postaci ziem Rzeczypospolitej (Gdańsk i Toruń, a być może część Wielkopolski)6. Ówczesna geopolityka europejska sprzyjała działaniom zmierzajaccym do aneksji Krymu, być może nawet $\mathrm{w}$ związku $\mathrm{z}$ sytuacją za oceanem.

${ }^{4}$ L. P o d h o r o d e c ki, Chanat krymski i jego stosunki z Polska $w$ XV-XVIII $w$, Warszawa 1987, s. 272.

5 W.A. S e r c z y k, Katarzyna II, Wrocław-Warszawa-Kraków 2004, s. 239.

${ }^{6}$ Historia dyplomacji polskiej, t. II (1572-1795), red. Z. Wójcik, Warszawa 1982, s. 571; W. Ko n o p c zy ń s ki, Fryderyk Wielki a Polska, Poznań 1947, s. 253. 
Imperatorowa wydała 8 kwietnia 1783 r. manifest, w którym ogłosiła przyłączenie Krymu do Rosji, obarczając Turcję wina za niedotrzymywanie traktatów oraz obiecujacc tolerancję dla ludności tatarskiej i zrównanie jej praw ze statusem odpowiednich stanów w państwie rosyjskim. Akcja wojskowa na Krymie dowodził generał (późniejszy generalissimus) Aleksander Suworow, który też doprowadził do abdykacji Szahin Gireja. Oficjalne przyłączenie ziem Chanatu Krymskiego do terytorium Rosji nastapiło 18 lutego 1784 r., kiedy Potiomkin przedłożył imperatorowej koncepcję utworzenia nowej jednostki administracyjnej.

Różne aspekty postawy władz Rzeczypospolitej w czasie aneksji Krymu przez Rosje były analizowane w literaturze przedmiotu. W ostatnich latach $z$ jednej strony Jerzy Michalski omówił sprawę ewentualnego przymierza polsko-rosyjskiego w tym okresie ${ }^{7}, z$ drugiej zaś Tadeusz Srogosz kwestię postawy dywizji ukraińskiej i podolskiej wobec wkroczenia armii rosyjskiej do Rzeczypospolitej w 1783 r. ${ }^{8}$ Pomijając już fakt funkcjonowania tych publikacji $\mathrm{w}$ ograniczonych kręgach odbiorców, brak jest w miarę pełnego obrazu polityki Rzeczypospolitej w sprawie krymskiej. Pewne tezy i oceny muszą do tego ulec weryfikacji.

Pierwszy rozbiór Rzeczypospolitej przyniósł zmiany w mentalności elit politycznych, które porzuciły bierność w polityce międzynarodowej na rzecz przesadnej wręcz wrażliwości na dokonujące się czy też przewidywane przeobrażenia konfiguracji w Europie. Powstawały projekty działań mogących zabezpieczyć lub nawet polepszyć sytuację międzynarodową, które jednak - jak je ocenił Jerzy Michalski - „pozostawały w dysproporcji do możliwości ich realizacji zarówno ze względu na brak własnych sił, jak i obojętność, a często i zdecydowana niechęć obcych państw, z których właściwie żadne nie pragnęło zaktywizowania Polski i Polaków”9. Właśnie w tym kontekście autor ten rozpatrywał kwestię ewentualnego przymierza Rzeczypospolitej z Rosja. Dodatkowymi czynnikami wzmacniającymi ten kierunek polityki zagranicznej były obawy o apetyty Prus na rekompensaty terytorialne $\mathrm{w}$ razie wzro-

7 J. Michalski, Sprawa przymierza polsko-rosyjskiego $w$ dobie aneksji Krymu, [w:] i d e m, Studia historyczne z XVIII i XIX wieku, t. I (Polityka i społeczeństwo), Warszawa 2007, s. 420-448.

8 T. S r o gos z, Dywizja ukraińska i podolska wobec wkroczenia armii rosyjskiej do Rzeczypospolitej w 1783 roku, „Naukowi praci istoricznowo fakultietu Zaporożskowo nacjonalnowo uniwiersitietu", t. XXVI, [Zaporoże] 2009, s. 133-137.

9 J. M i c hals ki, op. cit., s. 420. 
stu potęgi monarchii rosyjskiej, a zwłaszcza habsburskiej, oraz perspektywa, że południowo-wschodnie tereny Rzeczypospolitej stana się teatrem działań wojennych.

Stanisław August Poniatowski właściwie od początku swojego panowania liczył na zawarcie formalnego przymierza $z$ Rosja, co uważał za najbardziej skuteczne zabezpieczenie integralności terytorialnej Rzeczypospolitej. Taka linia polityczna stała się jeszcze bardziej aktualna w czasie kryzysu krymskiego. Dlatego król nie czekał biernie na rozwój wypadków, zabiegał o zapewnienia ambasadora Magnusa Stackelberga i Petersburga, o słowa zaprzeczajace woli nowych zaborów, w tym również zajęcia przez Prusy Gdańska, pozostającego zresztą od dłuższego czasu pod rosyjskim protektoratem ${ }^{10}$. Stanisław August w swoich planach bazował na niechęci Katarzyny II do uszczuplenia wpływów w Rzeczypospolitej, płacenia nabytkami terytorialnymi Prusom za tolerowanie zdobyczy tureckich. Król widział jednak w Petersburgu oznaki niechęci do reformowania Rzeczypospolitej, a także wpływy Potiomkina, zwłaszcza w kontekście zwiazku małżeńskiego jego oficjalnej siostrzenicy Aleksandry Engelhardt $z$ hetmanem wielkim koronnym Franciszkiem Ksawerym Branickim. Stanisław August Poniatowski z niepokojem odbierał wiadomości (głównie od generała Józefa Gabriela Stempkowskiego) o podróżach Branickich do Chersonia, gdzie coraz częściej przebywał Potiomkin.

W gronie polityków opozycyjnych powstawały projekty zmontowania przymierza Rzeczypospolitej z Rosją. Według Jerzego Michalskiego jednym $z$ autorów memoriału sporządzonego prawdopodobnie między 30 listopada 1782 r. a 3 września 1783 r. o przymierzu obronnym był wojewodzic poznański Jan Poniński, były działacz konfederacji radomskiej i barskiej, człowiek bliski hetmanowi Branickiemu i prowadzący korespondencję $z$ Potiomkinem ${ }^{11}$. Poniński obiecywał, że zdoła skłonić króla do współdziałania, a także wesprze swoimi stronnikami obóz hetmana Branickiego. Autor memoriału argumentował, że Rzeczpospolita nie jest w stanie egzystować bez poparcia Rosji, która nie zagraża jej integralności terytorialnej, wolności narodowej i republikańskiej formie rzadów. Dlatego konieczne jest zawarcie wieczystego przymierza zaczepno-odpornego $z$ Rosja w celu ochrony przed zaborczościa Prus i Austrii. Rzeczpospolita ma odgrywać rolę bufora chroniącego Ro-

10 Ibidem, s. 423.

11 Ibidem, s. 427. 
sję od agresji $z$ zachodu, a jednocześnie być bazą dla szerzenia wpływów rosyjskich w Rzeszy Niemieckiej. Konieczne jest zatem umieszczenie rosyjskich garnizonów wojskowych wzdłuż granic Rzeczypospolitej z Turcja, Austrią i Prusami.

Poniński sam zadeklarował, że przedstawi ów plan Potiomkinowi, a za jego pośrednictwem dworowi petersburskiemu. Wraz $z$ hetmanem Branickim skłoniłby Stanisława Augusta Poniatowskiego do akceptacji planu, a w razie braku zgody króla zamierzał zawiązać konfederację pod osłona bagnetów rosyjskich. Poniński podał listę wtajemniczonych w planowane działania, a nawet przewidywał zastapienie ambasadora Stackelberga bratem Potiomkina, Pawłem. Marszałkiem przyszłego sejmu miał zostać wojewoda podlaski Józef Ossoliński, który w maju 1783 r. gościł u hetmana Branickiego w Białej Cerkwi i spotkał się tam $z$ księciem Potiomkinem. Traktat przymierza powinien zawrzeć sejm na bardzo dobrych dla Rzeczypospolitej warunkach (zniesienie granicy z Rosja, co przyniesie znaczace korzyści handlowe). Zwiększony etat armii miał być prawie w całości zorganizowany jako korpus posiłkowy w wojnie rosyjsko-tureckiej i dowodzony przez hetmana Branickiego.

Według Jerzego Michalskiego plan Ponińskiego, wyrażający interesy Branickiego, za który Rzeczpospolita miała zapłacić dalszym uzależnieniem od Rosji, nie mógł być zaakceptowany $z$ różnych względów przez polityków w Petersburgu (antyaustriacki charakter planu, niechęć do zaangażowania sił zbrojnych w tworzenie kordonu przeciw Austrii i Prusom)12.

Zapewne w kwietniu 1783 r. w Białej Cerkwi powstał projekt memoriału autorstwa wojewody poznańskiego Augusta Sułkowskiego ${ }^{13}$, który jechał do Petersburga, ale najpierw chciał się naradzić $z$ hetmanem Branickim i księciem Potiomkinem. Sułkowski proponował utworzenie w Rzeczypospolitej „prawdziwej partii rosyjskiej", swoistej rady króla i ambasadora carycy. W tym celu należało zawiązać konfederację cywilna pod laska Augusta Sułkowskiego dla Korony i Kazimierza Nestora Sapiehy dla Litwy. Głównym zadaniem tych konfederacji będzie zawarcie przymierza za-

12 Ibidem, s. 429.

13 Tak wnioskował J. Michalski (ibidem, s. 433). Stanisław Sidorowicz, który opisał misję Sułkowskiego wcześniej i przytaczana przez którego większą część faktów Jerzy Michalski powtórzył, nie podał miejsca sporządzenia memoriału. Por. i d e m, Walka o moskiewski alians (1782-1784), „Polityka Narodów” 1936, t. VIII, z. 3, s. 256-282. 
czepno-obronnego z Rosja i ,jej aliantami”14. Memoriał zawierał punkt dotyczaccy odstapienia Prusom Gdańska i Torunia w zamian za objęte pierwszym rozbiorem kawałki Wielkopolski, a także złagodzenie obciążeń celnych polskiego handlu, oraz dopuszczenie do kontaktów z kupcami w Gdańsku, czyli zlikwidowanie monopolu w tym zakresie kupców gdańskich. Oprócz przymierza miałby zostać podpisany traktat handlowy, dotyczacy przede wszystkim kierunku czarnomorskiego. Rosja miała łożyć na ćwiczenia utworzonej przez konfederacje jednostek milicji, pozostającej pod wyłączna komenda hetmana Branickiego. Etat armii Rzeczypospolitej powinien wynosić 30 000, co Sułkowski uzasadniał względami fiskalnymi.

Jerzy Michalski stwierdził, że Potiomkin i dwór petersburski nie mogli przyjać wszystkich punktów memoriału, a w związku $z$ tym cały dokument nie znalazł akceptacji15. Chodzi tutaj przede wszystkim o reformy ustrojowe, czyli o pomysł wprowadzenia stałego sejmu oraz projekty ustanowienia po śmierci Stanisława Augusta Poniatowskiego republiki lub monarchii dziedzicznej $z$ obca dynastia na tronie. Jako sprawy dodatkowe memoriał wymieniał następujace kwestie: nadanie lenna kurlandzkiego Potiomkinowi (w przypadku jego bezpotomnej śmierci miało ono przypaść synom Branickiego); ustanowienie $z$ Multan, Mołdawii i Besarabii księstw polskich; przywrócenie prerogatyw władzy hetmańskiej jako podległej tylko sejmowi (Sułkowski proponował tutaj kompromis między zapisami w konstytucjach $z$ lat 1775 i 1776). Stanisław August Poniatowski zdementował pogłoski, jakoby Sułkowski występował $\mathrm{w}$ jego imieniu, prosząc nawet kasztelana bracławskiego Marcina Grocholskiego o zanegowanie tego faktu w rozmowie $z$ Potiomkinem ${ }^{16}$.

Ostatecznie do zawarcia traktatu nie doszło, być może $z$ tego powodu, że król nie był entuzjasta takiego rozwiązania. Chodziło mu raczej o stopniowe rozszerzanie przywilejów polskiego handlu, o co skutecznie zabiegali kasztelan bracławski Grocholski i Kajetan Chrzanowski w Chersoniu w maju i w czerwcu 1783 r.17 Je-

14 Jerzy Michalski rozszyfrował aliantów jako Austrię i Prusy. Por. i d e m, op. cit., s. 434.

15 Ibidem, s. 435.

16 M. Ma d zik, Polskie inicjatywy handlowe $w$ rosyjskich portach czarnomorskich na przełomie XVIII $i$ XIX wieku, Lublin 1984, s. 54-55.

17 Ibidem, s. 54-57. 
sienia 1783 r. król podjął decyzję o wysłaniu do Chersonia agenta handlowego. Został nim Antoni Zabłocki, który dotarł tam dopiero na wiosnę następnego roku, natomiast nowa placówka służby zagranicznej nie od razu uzyskała range konsulatu ${ }^{18}$. Zagospodarowanie terenów przyłączonych do Rosji po traktacie w Küdżuk Kainardżi i aneksja Krymu skutkowały zintensyfikowaniem polskich inicjatyw gospodarczych na kierunku czarnomorskim, zwłaszcza za pośrednictwem założonej w tym czasie Kompanii Handlu Czarnomorskiego ${ }^{19}$.

Stosunek Stanisława Augusta Poniatowskiego do ewentualnej wojny rosyjsko-tureckiej w literaturze przedmiotu przedstawiany jest w skrajnie różny sposób. Stanisław Sidorowicz podał, że w czerwcu 1783 r. król wydawał się zmartwiony oddaleniem perspektywy konfliktu militarnego, natomiast Jerzy Michalski uznał to stwierdzenie za niesłuszne ${ }^{20}$. Władysław Konopczyński ocenił postawę króla w sytuacji stosowania przez Rosję polityki faktów dokonanych jako umiarkowaną ${ }^{21}$. Niezależnie od stanowiska w sprawie ewentualnej wojny, w gabinecie królewskim przygotowywano projekt konfederacji, wzorowanej na akcie z 1776 r., dla zapewnienia spokoju wewnętrznego. Skonfederowany sejm miał zwiększyć

18 Ibidem, s. 58-59.

19 Ibidem, s. 59-67; A.J. R o 11 e, Poczatek handlu polskiego na Czarnym Morzu i żegluga po Dniestrze, [w:] i d e m, Wybór pism, t. II (Gawędy historyczne), oprac. W. Zawadzki, Kraków 1966, s. 5-15; J. F eld m a n, Projekty handlu polsko-francuskiego w XVIII w., [w:] Studia historyczne ku czci Stanisława Kutrzeby, t. II, Kraków 1938, s. 247-263; R. G a ziń s ki, Prusy a handel sola w Rzeczypospolitej $w$ latach 1772-1795, Warszawa 2007, s. 92-94; Z. G u 1 d o n, Handel Polski z Mołdawia, Nowoserbia $i$ Chersoniem w końcu XVIII w., [w:] Polska, Prusy, Ruś. Rozprawy ofiarowane prof. $z w$. dr. hab. Janowi Powierskiemu $w$ trzydziestolecie pracy naukowej, red. B. Śliwiński, Gdańsk 1995, s. 57-61; A. M i c h a ls ki, Działalność handlowo-gospodarcza szlachty polskiej $w$ miastach nadczarnomorskich u schyłku XVIII i poczatkach XIX w., [w:] Poljaki na piwdni Ukraini ta $w$ Krimu. Polacy na południowej Ukrainie i Krymie, red. T. Ciesielski, E. Czapiewski, W. Kusznir, Odessa-Opole-Wrocław 2007, s. 52-53. W powyższym zestawieniu pominięte zostały biogramy i nie wnoszace nowych treści prace, na przykład będacy kompletnym nieporozumieniem artykuł Krzysztofa Gębury (Związek Prota Potockiego z Chersoniem na tle panoramy gospodarczej Rzeczypospolitej Polskiej $w$ latach 1772-1795, [w:] $Z$ dziejów wojskowości polskiej. Księga jubileuszowa Profesora Kazimierza Pindla $w$ 70. rocznice urodzin, red. J. Gmitruk, W. Włodarkiewicz, Warszawa-Siedlce 2008, s. 76-81).

20 J. Michalski, op. cit., s. 423, przyp. 11; S. Sidorowicz, op. cit., s. 275 .

21 W. K o n o p c zyń s k i, Polska a Turcja 1683-1792, Warszawa 1936, s. 275. 
etat armii, podnieść dochody skarbu i zniwelować usterki ustrojowe $^{22}$. Widzimy zatem, że w otoczeniu króla dążono przy okazji konfliktu militarnego o Krym do przeforsowania chociaż częściowego programu reform.

Plan akcji przyłączenia Krymu przewidywał też wkroczenie żołnierzy rosyjskich na terytorium Rzeczypospolitej w celu ochrony skrzydła głównych sił inwazyjnych od strony Mołdawii i Wołoszczyzny, a być może Prus, ewentualnie zneutralizowania nastrojów szlachty polskiej (pamiętano o pomocy tureckiej dla konfederatów barskich). Od 1781 r., czyli od dymisji Nikity Panina i wzrostu wpływów Potiomkina, który był zwolennikiem rozluźnienia kurateli, na politykę zagraniczna, armia rosyjska nie stacjonowała w granicach Rzeczypospolitej23. Jednak wobec planów aneksji Krymu zaszła polityczna i strategiczna konieczność szerzej zakrojonych działań.

Armia rosyjska przekroczyła granicę prawdopodobnie około połowy czerwca $1783 \mathrm{r}$. Władze rosyjskie nie poczuwały się przy tym do obowiazku powiadomienia władz Rzeczypospolitej o tym fakcie, a tym bardziej zapytania ich o zgodę. W tej przymusowej sytuacji Rada Nieustająca ogłosiła neutralność Rzeczypospolitej. W liście do generała Józefa Gabriela Stempkowskiego z 20 czerwca 1783 r. Stanisław August informował, że na posiedzeniu Rady Nieustającej odczytano raport o wkroczeniu dwóch korpusów rosyjskich $^{24}$. Pierwszym korpusem dowodził książę generał (późniejszy feldmarszałek) Nikołaj Repnin, który wcześniej sprawował funkcję ambasadora w Warszawie. Repnin swoja kwaterę ustanowił w Humaniu. Na czele drugiego korpusu stał hrabia generał (późniejszy feldmarszałek) Nikołaj Sołtykow, ówczesny wiceprzewodniczący Kolegium Wojny (od 1788 r. przewodniczaccy). Sołtykow stacjonował w Niemirowie 25 . W październiku 1783 r. władze oceniły, że w granicach Rzeczypospolitej przebywało 60000 żołnierzy rosyjskich (szczegółowy etat korpusów rosyjskich przedstawił 22 grudnia $1783 \mathrm{r}$. generał Karol Skarbek Malczewski) ${ }^{26}$. Zgrupowanie tak dużych sił

22 J. Mich a $1 \mathrm{ski}$ i, op. cit., s. 442.

23 T. S rogos z, Zakres działalności Rady Nieustajacej $w$ systemie politycznym Rzeczypospolitej w latach 1775-1788, „Prace Naukowe Wyższej Szkoły Pedagogicznej w Częstochowie” 1998, ser. Zeszyty Historyczne, z. 5, s. 191.

${ }^{24}$ Biblioteka Czartoryskich w Krakowie [dalej: BCz], rkps 688, s. 501-502.

25 W. Konopczyński podał błędnie, że w Kamieńcu Podolskim (loc. cit.).

${ }_{26} \mathrm{BCz}$, rkps 688, s. 628; Archiwum Główne Akt Dawnych w Warszawie [dalej: AGAD], Militaria z Jabłonny nr 4, s. 604-606. 
przez Rosjan miało uzasadnienie strategiczne, gdyż ewentualny atak armii tureckiej mógłby nastapić od strony Półwyspu Bałkańskiego. Król zalecał Stempkowskiemu zachowanie spokoju, unikanie kontaktu $z$ Rosjanami. Stempkowski miał dobrać zdolnych oficerów, którzy udadzą się do kwater dowódców rosyjskich, i poinstruować ich co do zasad rozmów w sprawie zapobiegania krzywdom mieszkańców. Należało też szybko raportować (nie szczędząc sztafet) o ruchach wojsk rosyjskich, tureckich i austriackich.

Stempkowski był wówczas dowódca dywizji ukraińskiej i podolskiej, a jednocześnie sprawował nadzór nad umocnieniami w pobliżu rzeki Dniestr. Partia ukraińska i podolska powstała w 1768 r. Dowodził nia wtedy Franciszek Ksawery Branicki, ale od roku 1769 jej regimentarzem został Stempkowski, który w dowód zasług (głównie za tłumienie powstania hajdamaków i chłopów) otrzymał w roku 1772 kasztelanię kijowska, a po reorganizacji armii stopień generała lejtnanta. Po reformie w 1776 r. partia nazwana została dywi$z j a$, składająca się głównie $z$ brygad kawalerii narodowej. Brygady kawalerii narodowej utworzono $z$ choragwi husarskich i pancernych. Poszczególne brygady i inne jednostki dywizji rozlokowane były w województwach kijowskim, bracławskim i podolskim (partie i dywizje tworzono wówczas na zasadzie terytorialnej). Dowodzący dywizja ukraińska i podolska był doświadczonym oficerem i wytrawnym politykiem, kierujacym stronnictwem królewskim na Ukrainie (zwłaszcza w województwie kijowskim) ${ }^{27}$. Ponadto miał on pod swoją komendą doświadczonych i zdolnych oficerów w randze generała majora: Rafała Dzierżka, Rocha Jerlicza, Stefana Lubowidzkiego, Karola Skarbka Malczewskiego, Michała Zielonkę, a także innych, na przykład ówczesnego porucznika Macieja Perekładowskiego (w 1793 r. został generałem majorem). W 1783 r. trwały już rozmowy Stempkowskiego $z$ wojewoda ruskim Szczęsnym Potockim na temat sprzedaży dywizji, ale nastapiło to dopiero w na-

27 A. K a miń s k a, Stempkowski (Stępkowski) Józef Gabriel, [w:] Polski słownik biograficzny, t. XLIII, Warszawa-Kraków 2005, s. 385-392; T. S rogos z, Poczatki budowy stronnictwa królewskiego na Ukrainie przez Józefa Gabriela Stempkowskiego (koniec lat sześćdziesiatych - poczatek siedemdziesiatych XVIII w.), „Przegląd Nauk Historycznych” 2006, R. 5, nr 1 (9), s. 171-183; i d e m, Pokonanie hajdamaków jako podstawa znaczenia Józefa Gabriela Stempkowskiego na prowincji szlacheckiej, [w:] Ukrainsko-polskij naukowij diałog w Umani, Humań 2009, s. 195-203; idem, „Strasznyj Józef” - gienierał Józef Gabriel Stempkowskij $i$ jogo borotba $z$ hajdamakami w 1768-1771 rr., „Kiiwska Starowina” 2005, nr 2 (362), s. 60-74. 
stępnym roku, po interwencji Stanisława Augusta Poniatowskiego. Król pisał 18 września 1783 r. do Stempkowskiego: „Ani WP myśl teraz o składaniu komendy. Teraz tak jak czynisz, czyniąc zarabiasz na sławę, a gdybyś porzucił, sam byś siebie skrzywdził, a mnie byś dotkliwie zmartwił. Upewniam zaś, że się na mojej wdzięczności nie zawiedziesz, gdy dotrzymasz plan do końca w tak potrzebnym czasie"28. Być może decyzja o odłożeniu sprzedaży dowództwa dywizji przyczyniła się m.in. do rychłego uzyskania godności wojewody kijowskiego.

Stempkowski, stosownie do poleceń, wysyłał raporty do Warszawy o rozlokowaniu wojsk rosyjskich nie tylko w południowowschodnich województwach Korony, lecz także w pobliżu jej granic (zwłaszcza w okolicach Chersonia i na Krymie). Dowódca dywizji ukraińskiej i podolskiej twierdził, że w związku z zaistniała sytuacja należy umacniać jednostki wojskowe, zbroić się, prowadzić akcję wywiadowczą. Obawiał się, że rzekę Dniestr przekroczy armia turecka ${ }^{29}$. Jednocześnie sytuacja stawała się jeszcze bardziej trudna $z$ racji rozprzestrzeniajacej się od strony Krymu i Chersonia epidemii dżumy ${ }^{30}$. Dowódca dywizji ukraińskiej i podolskiej liczył się $\mathrm{z}$ faktem, że będzie musiał $\mathrm{w}$ związku $\mathrm{z}$ zarazą wydać rozkazy o translokacji pododdziałów, co może wywołać podejrzenia Rosjan o podejmowanie nieprzyjaznych wobec nich kroków.

Dowódcy rosyjscy próbowali dezinformować dowództwo dywizji ukraińskiej i podolskiej, rozsiewali pogłoski o nawoływaniu przez Stempkowskiego szlachty ukraińskiej i wołyńskiej do zawiązania konfederacji. Kluczowa rolę w tej akcji odegrał feldmarszałek Siemion Szyrkow, sprawujący wówczas funkcję gubernatora kijowskiego. Na przełomie czerwca i lipca 1783 r. gościł u niego w Kijowie starosta krzemieniecki Janusz Modest Sanguszko z małżonka Aniela $z$ Ledóchowskich, siostra żony Szyrkowa. W tym czasie przebywał tam również Sołtykow. Gubernator kijowski rozpytywał Sanguszkową o lokalizację miejsca pobytu Stempkowskiego i wojewody ruskiego Potockiego, o charakter zjazdu szlachty i oficerów w rezydencji dowódcy dywizji ukraińskiej i podolskiej w Łabuniu, a także o terminarz posiedzeń Rady Nieustajacej w Warszawie (Stempkowski był wówczas jej konsyliarzem). Sanguszkowa „już

${ }^{28} \mathrm{BCz}$, rkps 688, s. 586.

29 Ibidem, s. 523-525.

30 T. S r o g o s z, Dżuma ujarzmiona? Walka z czarna śmiercia za Stanisława Augusta, Wrocław 1997, s. 109-114. 
wiedziała od Szyrkowej, jak ma na wszystko odpowiadać, a zakończyła, że Łabuń zwyczajny dla gości"31. Szyrkow, aby rozładować sytuację, chwalił bardzo kawalerię narodowa, na co „Sołtykow generał, nachyliwszy się do Sanguszkowej, powiedział, że spodziewamy się wkrótce i tę kawalerię i ich generała Stempkowskiego mieć w swojej komendzie"32. Stanisław August Poniatowski na te $\mathrm{w}$ istocie antykrólewskie (Stempkowski był przecież przywódca jego stronnictwa na Ukrainie i Wołyniu) doniesienia reagował spokojnie, zauważając, że Szyrkow zazdrości dowódcy dywizji ukraińskiej i podolskiej pozycji w Rzeczypospolitej.

W pierwszej połowie lipca 1783 r. komendy rosyjskie rozlokowały się $\mathrm{w}$ różnych punktach południowo-wschodnich terenów Korony. Wraz z tym zaistniał problem dezerterów. Stempkowski raportował, że zgłosił się do niego rosyjski porucznik poszukujący zbiegłych żołnierzy ${ }^{33}$. Tymczasowo dowódca dywizji ukraińskiej i podolskiej rozkazał, aby nie wydawać Węgrów i Polaków, ale musi mieć w tym zakresie dyspozycje od Departamentu Wojskowego Rady Nieustającej. Problem dezerterów występował nieustannie w okresie stacjonowania armii rosyjskiej w Polsce. Taktyka Stempkowskiego polegała niezmiennie na zwlekaniu $z$ ich przekazaniem, aczkolwiek obligowała go do tego rezolucja Rady Nieustajacej z $1777 \mathrm{r}$.

Narastał również problem zaopatrzenia żołnierzy rosyjskich w żywność i furaż, a w związku $z$ tym ewentualnych grabieży i innych nadużyć. Spodziewano się, że korpusy Repnina i Sołtykowa pozostana na zimę, dlatego konieczne stało się wyznaczenie komisarzy przy wojsku carskim. Jednak względy ustrojowe nie pozwalały na szybka ich nominację, ponieważ mogły to uczynić tylko sejmiki gospodarskie (lub dać pełnomocnictwo Stempkowskiemu). O wyznaczenie komisarzy upominali się także generałowie rosyjscy, którzy szybko uznali procedury formalne za zbyt powolne i przejęli w tym względzie inicjatywę. Przy okazji wizyty w Białej Cerkwi Szyrkow poprosił cześnika kijowskiego Kajetana Suszczańskiego Proskurę, aby przejął obowiązki komisarza $z$ województwa kijowskiego przy korpusach rosyjskich ${ }^{34}$.

\footnotetext{
${ }^{31} \mathrm{BCz}$, rkps 688, s. 509.

32 Ibidem.

33 Ibidem, s. 526.

34 Ibidem, s. 527.
} 
Sprawa komisarza $z$ województwa kijowskiego nie została jednak szybko załatwiona $z$ powodu postawy Stempkowskiego, który zwlekał $z$ nominacja, mimo interwencji generałów rosyjskich, a nawet ambasadora Stackelberga. Nie chodziło tutaj bynajmniej o kandydaturę Proskury, ale o niechęć do Rosjan i fakt naruszenia przez nich granic Rzeczypospolitej. Świadczy o tym list Stempkowskiego do Sołtykowa z 15 września 1783 r., w którym wprawdzie zapewnia, że cześnik kijowski jest już zapewne w Niemirowie, ale jednocześnie stwierdza: „Polska nie spodziewała się wkroczenia wojsk zagranicznych" 35 . Dowódca dywizji ukraińskiej i podolskiej nie był łatwym rozmówca dla Rosjan. Ustapił dopiero po wyraźnym poleceniu króla, który napisał, że skoro sejmik gospodarski w Żytomierzu dał mu takie pełnomocnictwo, to niech wyznaczy komisarza, „aby uniknać wszelkiej okazji skarg i wymówek”36. Stanisław August Poniatowski uczestniczył w planie utrudniania pobytu armii rosyjskiej w Rzeczypospolitej.

Komisarz Proskura rozpoczał swoje czynności w kwaterze Soltykowa w Niemirowie prawdopodobnie pod koniec września $1783 \mathrm{r}$. Do połowy następnego miesiąca wydał dyspozycje odnośnie do dostaw żywności i furażu, zajmował się także sprawą poczty. Wcześniej Repnin interweniował u ambasadora Stackelberga, że generał Malczewski utrudniał kurierom rosyjskim przejście od Krzywego Jeziora do Józefgrodu przez dobra Szczęsnego Potockiego, tłumaczacc swoja postawę brakiem kompetencji, a wreszcie koniecznością utrzymania zabezpieczeń przeciwdżumowych. Repnin twierdził, że może to wymusić na dowódcach i urzędnikach koronnych, ale woli załatwić sprawę pokojowo. W tym samym czasie hetman Branicki nie życzył sobie, aby kurierzy rosyjscy przejeżdżali przez jego dobra białocerkiewskie. Dowódcy dywizji ukraińskiej i podolskiej oraz komisarz Proskura ostatecznie załatwili problem po myśli Rosjan.

W październiku 1783 r. cześnik kijowski wydał pięciopunktowe zalecenie dotyczące dostarczania żywności i furażu żołnierzom rosyjskim, ale nie zadowolił tym mieszkańców województwa kijowskiego. Właścicielom majątków ziemskich nie odpowiadały pokwitowania, ponieważ Rosjanie nie wypłacili pieniędzy za produkty wybierane $\mathrm{w}$ poprzednich latach. Wymieniona $\mathrm{w}$ zaleceniu jako ekwiwalent miedź ruska nie miała według szlachty kursu (na

\footnotetext{
35 Ibidem, s. 596.

36 Ibidem, s. 580.
} 
przykład za zboże sprzedający otrzymywał tylko połowę wartości $\mathrm{w}$ miedzi ruskiej) ${ }^{37}$. Proskura oceniał nawet generałów rosyjskich, być może na prośbę Stempkowskiego. Na przykład Sołtykowa opisał jako słabego dowódcę (,jakby nie generał”), raczej słuchającego swoich podkomendnych, a nie wydajacego rozkazy 38 .

Dowódcy poszczególnych komend wojskowych mieli duże kłopoty $z$ maszerującymi Rosjanami, nie pytającymi się bynajmniej władz Rzeczypospolitej o zgodę. Najpoważniejszy problem powstał $z$ powodu przemarszu przez Wielkie Księstwo Litewskie kilkusetosobowego oddziału piechoty kozackiej pod dowództwem podpułkownika Fadiejewa. O tym incydencie Stempkowski dowiedział się pod koniec sierpnia 1783 r. $z$ listu starościny żmudzkiej Ludwiki Marii Chodkiewiczowej, nie zaś od dowództwa armii litewskiej, o co miał słuszne pretensje ${ }^{39}$. Kozacy poszukiwali na Litwie dawnych dezerterów $z$ armii rosyjskiej (wywiezieni zostali w głąb Rosji), a po zrealizowaniu zadania przeprawili się przez Prypeć i zatrzymali w dobrach starościny żmudzkiej w Ładoszycach niedaleko Czarnobyla w województwie kijowskim, oczekując dalszych rozkazów. Stempkowski tak opisał ekscesy Fadiejewa w Wielkim Księstwie Litewskim: „Wybrał kilka tysięcy chłopów, zaznaczył się biciem tyrańskim i zabijaniem na śmierć skarbowych oficjalistów, zabieraniem pieniędzy skarbowych, nakładaniem kontrybucji na obywatelów"40. Przemarsz oddziału Fadiejewa nie był prawdopodobnie częścia planu związanego $z$ opanowaniem Krymu. Tak przynajmniej sądził Stempkowski, który napisał o tym incydencie wprost do feldmarszałka Piotra Rumiancewa, natomiast Repnina i Sołtykowa tylko zdawkowo na ten temat poinformował (Sołtykow stwierdził wprost, że nic nie wie o Fadiejewie).

Dowódca dywizji ukraińskiej i podolskiej na incydent zwiazany $z$ wkroczeniem oddziału Fadiejewa zareagował spokojnie, aczkolwiek zdecydowanie. Natychmiast wysłał w okolice Czarnobyla 30 żołnierzy kawalerii narodowej pod dowództwem porucznika Jana Zarzeckiego $z$ rozkazem niedopuszczania w miarę możności do wybierania prowiantów i furażu, używając do tego celu milicji nadwornych. Stempkowski nie dał mu większej liczby ludzi, ponieważ obawiał się potyczki $z$ Rosjanami. Zarzecki wywiązał się z zadania

\footnotetext{
37 Ibidem, s. 639.

38 Ibidem, s. 622.

39 Ibidem, s. 563-564.

40 Ibidem, s. 596.
} 
znakomicie. Nie mógł wprawdzie zapobiec wybieraniu przez Rosjan żywności i furażu, ale nie dopuścił do ścigania dezerterów w województwie kijowskim. Stempkowski tak ocenił położenie Fadiejewa: „widzi, że na około opasany, jednak wie o tym, że powrót ma łatwy i wolne między memi komendami przejście, aby tylko ludzi nie wybierał, furaże i prowianty darmo bierze, mówiąc głośno, że ma taki rozkaz"41.

W sprawie stacjonowania w rejonie Czarnobyla oddziału Fadiejewa interweniowały różne osoby. Dowódca dywizji ukraińskiej i podolskiej słał listy w tej materii do Repnina, Sołtykowa, Rumiancewa, a także do hetmana Branickiego, aby ten w czasie wizyty $\mathrm{w}$ Chersoniu prosił Potiomkina o pomoc w usunięciu oddziału kozackiego. Stanisław August Poniatowski przede wszystkim zalecał, „aby w takim razie nasze żołnierstwo pierwsi nie atakowali, ani strzelali” oraz, aby Stempkowski nie wyjeżdżał z Ukrainy „póki się ta awantura nie skończy"42. Król poinformował natychmiast ambasadora Stackelberga o incydencie, a ten wydawał się zainteresowany końcem awantury Fadiejewa. Stanisław August Poniatowski słał również listy do Petersburga. Wreszcie, po długich zabiegach dyplomatycznych, wywiadowczych i osobistych, decyzję o powrocie do Rosji oddziału kozackiego wraz $z$ obietnica wyrównania krzywd właścicielom majątków ziemskich wydała sama Katarzyna II. W celu przypilnowania wymarszu, dowódca dywizji ukraińskiej i podolskiej udał się w pobliże Czarnobyla. Po początkowej zwłoce Fadiejew ze swym oddziałem wyruszył 7 października 1783 r. z Radomyśla do Rosji, ale znów przez obszar Wielkiego Księstwa Litewskiego. Zarzecki towarzyszył Rosjanom do Łojowa, a dalej eskortę przejęli Litwini.

Dowódcy rosyjskich korpusów, nie zważając na stacjonujące jednostki dywizji ukraińskiej i podolskiej, postanowili zajać jak najlepsze pozycje $z$ punktu widzenia ewentualnych operacji wojennych. Takie możliwości dawała miejscowość Ilińce, gdzie na leżach przebywała zwykle trzecia brygada kawalerii narodowej pod dowództwem generała Lubowidzkiego (tam też był sztab brygady). Już 25 sierpnia 1783 r. Stempkowski raportował do Warszawy, że rosyjski oddział chciał siła zając Ilińce, ale Sołtykow ustapił i rozkazał swoim podkomendnym odmaszerować $z$ tej okolicy ${ }^{43}$.

\footnotetext{
41 Ibidem, s. 590.

42 Ibidem, s. 586.

43 Ibidem, s. 564.
} 
Sprawa powróciła na początku października 1783 r., kiedy Sołtykow zażądał, aby $z$ tej miejscowości usunąc sztab trzeciej brygady. W zwiazku $z$ tym Stempkowski rozkazał generałowi Lubowidzkiemu, „aby nic nie mówiąc nikomu, czynił gotowość pomknięcia się do Berszady, a furaże, prowianty, na cała zimę przysposobione, bezcennie przedawać będa musieli" ${ }^{4}$. Awantura o stanowiska w Ilińcach trwała miesiąc. Sołtykow tłumaczył, że w miejscowości tej maja być zorganizowane tylko kwatery dla szefa sztabu jego korpusu, groził, pisał skargi do ambasadora Stackelberga ${ }^{45}$. Dowódca dywizji ukraińskiej i podolskiej z kolei grał na zwłokę, tłumacząc się oczekiwaniem na rozkazy Departamentu Wojskowego, pozornie tylko hamując opór swych oficerów. Ustapienie $z$ miasteczka Ilińce rujnowało Stempkowskiemu rozlokowanie dywizji, „a na skrzydłach i $z$ tyłu Moskale. Zawsze dwa przypadki czekaja, albo Turcy albo hajdamacy wytna, albo powietrze zarazi"46. Porucznik Perekładowski nie wpuścił Rosjan do zamku, twierdząc, że nie obejdzie się bez bitwy. W końcu jednak, po interwencji Stanisława Augusta Poniatowskiego i rozkazie Stempkowskiego, ustapił z zamku i miasteczka.

Rosjanie, wbrew wcześniejszym deklaracjom, maszerowali głównie przez terytorium województw kijowskiego, bracławskiego $\mathrm{i}$ podolskiego, kwaterowali na przykład w Wołodarce (mimo zwolnienia tego miasteczka od stacjonowania żołnierzy rosyjskich), widziano ich oddział, w sile 500 żołnierzy, w miejscowości Strzeszyn. W Chwastowie doszło nawet do walki o stanowiska. Obrażeń doznali żołnierze rosyjscy, ale też jeden $z$ oficerów dywizji ukraińskiej i podolskiej został pobity i zraniony w rękę biała bronią.

Dowództwo dywizji ukraińskiej i podolskiej prowadziło w związku z sytuacja wokół aneksji Krymu szeroko zakrojona akcję wywiadowcza. Pomijam tu normalne czynności związane ze zbieraniem danych o siłach i środkach oraz rozlokowaniu korpusów Repnina i Sołtykowa oraz oddziału Fadiejewa. Gromadzenie tych danych i informowanie o nich przełożonych należało do obowiązków wszystkich szczebli dowodzenia dywizji. Chodziło tutaj o wywiad zagraniczny - działania Potiomkina, reakcję Turcji i innych państw. Czasem prace wywiadowcze prowadzone były pod pretekstem rozpoznania epidemii dżumy, która w Rzeczypospolitej wy-

\footnotetext{
44 Ibidem, s. 610.

45 AGAD, Militaria z Jabłonny nr 1, s. 191-195.

$46 \mathrm{BCz}$, rkps 688, s. 623-624.
} 
stapiła na terenach przygranicznych od strony Chersonia i na $\mathrm{Hu}-$ mańszczyźnie.

Dowódca dywizji ukraińskiej i podolskiej od początku miał pewność co do celów polityki rosyjskiej. 27 lipca 1783 r. Stempkowski pisał do Stanisława Augusta Poniatowskiego: „Zapomniałem donieść WKMci, iż cel wyjazdu do Krymu księcia Potemkina jest ten, aby publikować deklarację, czyli manifest, iż chan tatarski dobrowolnie oddał całe państwo imperatorowej"47. Niespełna miesiąc później do Stempkowskiego dotarły wieści o poddaniu kraju przez Szahin Gireja, otrzymaniu przez niego orderu św. Andrzeja i o spodziewanym wyjeździe do Petersburga. Jak informował króla, starszyzna tatarska „po otrzymaniu dwóch pudeł kosztowności złożyła przysięgę na wierność imperatorowej. Wszyscy oczekuja, jak przyjmie to Turcja, ale wielu twierdzi, że spokojnie, chociaż poseł francuski dodaje im do wojny ochoty"48. Do listu do króla Stempkowski załączył wiadomości o dywizji rosyjskiej stacjonującej na Krymie. 13 września 1783 r. dowódca dywizji ukraińskiej i podolskiej wspominał o ciężkiej chorobie Potiomkina i innych osobistości w nadgranicznych guberniach, a po trzech tygodniach o pobycie faworyta carycy w Smoleńsku i jego dalszej podróży do Petersburga ${ }^{49}$.

Stempkowskiego interesowały ewentualne działania Turków, ale jego informacje były $z$ reguły uspokajajace. Tylko raz wywiad dywizji ukraińskiej i podolskiej uzyskał informację o marszu oddziałów tureckich $z$ Bukaresztu w stronę Chocimia. Stempkowski nie widział jednak raczej możliwości konfliktu rosyjsko-tureckiego, choćby $z$ racji zgromadzenia przez Rosjan niewielkich tylko zapasów w magazynach (na $10 \mathrm{dni}$ ). Na początku października $1783 \mathrm{r}$. przebywający w Turcji Kozacy Zaporoscy przeszli „suchą granica” na terytorium Rzeczypospolitej, napadli na posterunek dywizji ukraińskiej i podolskiej we wsi Okno między Raszkowem a Bałta i skradli 12 koni ${ }^{50}$. Dowódca posterunku, namiestnik Franciszek Jeziernicki, za niedbałość został aresztowany i oddany pod sąd wojskowy.

\section{Ibidem, s. 549.}

48 Ibidem, s. 564.

49 Pod koniec sierpnia 1783 r. książę Potiomkin zapadł na niebezpieczna gorączkę, jednak w połowie września nastąpiło już polepszenie stanu jego zdrowia. Por. S.S. M o n t e fi o r e, op. cit., s. 302.

$50 \mathrm{BCz}$, rkps 688 , s. 623. 
W następnych tygodniach napady powtarzały się, niewątpliwie $z$ inspiracji władz tureckich. Dla Stempkowskiego i władz w Warszawie napady Kozaków Zaporoskich i panująca zaraza stanowiły argument, że posterunków dywizji ukraińskiej i podolskiej nie można wycofać znad rzeki Dniestr (chodziło zwłaszcza o posterunki w Józefgrodzie Bałta oraz Berszadzie) i „ustapić ich” armii rosyjskiej.

W związku z działaniami armii rosyjskiej odżyły pogłoski o majacym nastapić podziale Rzeczypospolitej, które rozsiewali hetman Seweryn Rzewuski i kasztelan bracławski Grocholski. Według tych pogłosek Rosja miała zając ziemie po rzekę Słucz, Austria do linii Kraków-Puławy-Krzemieniec-Jampol-Kamieniec Podolski, a Prusy województwa wielkopolskie $z$ Księstwem Mazowieckim i Warszawa. Stanisław August Poniatowski uspokajał Stempkowskiego, który jednak w dalszym ciagu okazywał niepokój: „niechby tyle Miłościwy Królu zostało, bym nieszczęśliwą tę pewność wiedział, a resztę pozostałego wyprzedał majatku, jakbym się miał sromotnie gdzie dostać" 51 .

Na początku listopada 1783 r. wydawało się, że korpusy rosyjskie pozostaną dłuższy czas na terytorium Rzeczypospolitej, ponieważ poszczególne oddziały udały się na leża zimowe. Korpus Sołtykowa rozlokował się w województwie bracławskim, głównie w powiecie latyczowskim, od Niemirowa przez Winnicę do Nowego Konstantynowa. O korpusie Repnina brak danych źródłowych. Po akceptacji przez Turcję drugiej konwencji w Ainali-Kawak, zawartej na początku 1784 r. ${ }^{52}$, armia rosyjska opuściła jednak granice Rzeczypospolitej.

Po wkroczeniu korpusów rosyjskich i oddziału Fadiejewa, w kontekście konfliktu wokół Krymu, epidemii dżumy etc. sytuacja dywizji ukraińskiej i podolskiej stała się trudna. W tych warunkach dowódca dywizji, generał lejtnant Stempkowski, nie mając możliwości podjęcia bardziej zdecydowanych działań, grał na zwłokę, tłumaczył postawę swoją i swoich podkomendnych tak zwanymi trudnościami obiektywnymi, kierował pracami wywiadowczymi dotyczacymi jednostek rosyjskich i sytuacji poza granicami państwa.

51 Ibidem, s. 591.

52 Do uznania aneksji Krymu skłonili Turcję Francuzi, zabiegający w Petersburgu o uzyskanie przywilejów dla kupców zagranicznych w Chersoniu i liczący na korzyści w handlu czarnomorskim. Por. J. F eld m a n, op. cit., s. 256; W. Kon o p c zyńs ki, Fryderyk Wielki..., s. 257. 
Taktyka Stempkowskiego miała pełne poparcie Stanisława Augusta Poniatowskiego. Król znał swojego faworyta od niemal 30 lat i w pełni mu ufał, potrzebował go wprawdzie w Warszawie, ale wobec wydarzeń z roku 1783 życzył sobie, aby Stempkowski pilnował spraw na kresach południowo-wschodnich. W trudnych okolicznościach kontaktów $z$ armią rosyjską sprawdziła się zdecydowana większość kadry dowódczej dywizji.

Agnieszka Kamińska napisała, że Stempkowski jako jedyny dowódca w Rzeczypospolitej podjał próbe czynnej obrony przeciw Rosjanom ${ }^{53}$. Tę tezę należy jednak zdecydowanie odrzucić. Faktem jest, że dowódca dywizji ukraińskiej i podolskiej nie był łatwym rozmówca, podejmował wiele czynności w celu zahamowania nadużyć i zajmowania przez żołnierzy rosyjskich posterunków lub reagował bardzo opieszale na żądania carskich generałów, natomiast nie zaświtała mu nawet myśl o jakimkolwiek czynnym oporze. Zacytowany przez tę autorkę fragment listu kasztelana kijowskiego do króla nie świadczy bynajmniej o jego determinacji podjęcia kroków wojennych, które przecież - wobec postawy Stanisława Augusta Poniatowskiego - graniczyłyby $z$ awanturnictwem.

W zwiazku $z$ wydarzeniami w $1783 \mathrm{r}$. nasuwa się zreszta pytanie o możliwość czynnego przeciwstawienia się agresji sąsiadów i naruszenia suwerenności Rzeczypospolitej. Trudno jest na nie udzielić jednoznaczna odpowiedź. Według jednych dla Stanisława Augusta Poniatowskiego nigdy nie nastapił sprzyjający po temu moment $z$ powodu jego cech osobowości, zwłaszcza zaś manifestowanego serwilizmu wobec Katarzyny II i Rosji oraz całkowitego braku ducha wojennego. Być może zbrojne wystapienie przeciwko korpusom Repnina i Sołtykowa w trakcie aneksji Krymu spowodowałoby mobilizację Porty Ottmomańskiej do działań militarnych, a co za tym idzie wywołanie szerszego konfliktu militarnego. Na niekorzyść takiego stanowiska przemawia fakt, że Rosjanie w ogóle nie brali pod uwage podobnego wariantu (obawiali się natomiast postawy innych państw, zwłaszcza Prus). Ponadto nic nie wiemy o ewentualnych rozmowach na temat współdziałania politycznego i wojskowego $z$ Turcja. Według opinii innych autorów w żadnym momencie dziejowym schyłku I Rzeczypospolitej nie wystąpiły okoliczności sprzyjające zbrojnemu przeciwstawieniu się kurateli rosyjskiej. Należało raczej czekać, modernizować państwo i społeczeństwo, bez wojennych manifestacji. W warstwie interpretacyjnej

53 A. K a mińs k a, op. cit., s. 388. 
poruszamy się więc w sferze dawnego sporu szkoły krakowskiej i warszawskiej.

Jerzy Michalski tak oto podsumował wysiłki dyplomatyczne $z$ lat 1782-1784: „Wynikajaca $z$ braku sił i środków pozorność polskich projektów i działań politycznych w okresie przesilenia krymskiego nie zmienia faktu, że stanowiły one zapowiedź wydarzeń, które kilka lat później istotnie wpłynęły na losy Rzeczypospolitej. Poznanie tego, czego chciano dokonać w latach 1782-1784 pozwala lepiej zrozumieć motywy decyzji zarówno strony polskiej, jak i rosyjskiej w przełomowych latach 1788-1789. Dla Stanisława Augusta uzyskanie wreszcie zgody Katarzyny II na zawarcie przymierza i na skonfederowanie sejmu wydawać się musiało sukcesem po fiasku wcześniejszych starań. Oferty współpracy składane dworowi petersburskiemu przez ludzi szukających protekcji Potiomkina, a kierujących się własnymi ambicjami i korzyściami, umacniały dwór ten w przekonaniu, że zawsze znajdzie w Rzeczypospolitej polityków dyspozycyjnych, lepiej służących jego interesom niż król prorosyjski $z$ przekonania, ale którego celem było dobro państwa" ${ }^{54}$. Intencja imperatorowej było trzymanie tych ludzi w rezerwie jako narzędzia nacisku i szachowania, co wykorzystała w 1792 r. Sam jednak Jerzy Michalski podkreślił stosowanie przez imperatorową identycznych metod w latach sześćdziesiątych i siedemdziesiatych XVIII w. W takim razie wydarzenia $z$ okresu aneksji Krymu nie wnosiły nowych doświadczeń do polityki dworu petersburskiego. Co najwyżej mogły one krystalizować opozycję antykrólewska wokół ośrodka w Chersoniu, aczkolwiek $z$ drugiej strony pewnie bez wydarzeń z 1783 r. i tak hetman Branicki oraz inne osoby wiazałyby swoje plany polityczne $z$ Potiomkinem. Dodatkowo opozycjoniści mogli się obawiać o stan swoich dóbr w kontekście przemarszów i stacjonowania żołnierzy rosyjskich.

Trudno jest też ocenić znaczenie doświadczeń militarnych z 1783 r. dla późniejszych działań wojennych. W końcu zarówno dowódcy rosyjscy znali teren ewentualnego teatru działań, organizację armii koronnej i jej oficerów, jak również żołnierzom wszystkich szczebli dowodzenia dywizji ukraińskiej i podolskiej nieobca była armia rosyjska. W tym kontekście negatywnie należy ocenić czystkę wśród dowódców dywizji kijowsko-bracławskiej, jakiej dokonał książę Józef Poniatowski w 1791 r. (między innymi dotknięci jego metodami i ocenami byli generałowie Dzierżek i Lubowidzki,

54 J. M ich a 1 s ki, op. cit., s. 448. 
a być może również Malczewski, który sam „zrezygnował” ze stanowiska dowódcy dywizji wielkopolskiej). W zwiąku $z$ przemarszem oddziału podpułkownika Fadiejewa słabość okazała armia litewska, co pewnie dla nikogo nie było zaskoczeniem. Dla dowódców rosyjskich cenna mogła być jedynie informacja o niedostatku współdziałania i wzajemnego powiadamiania między armiami litewską i koronną. 